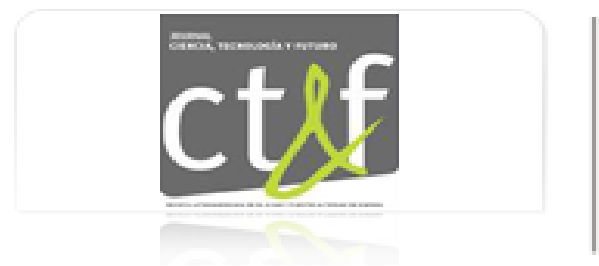

CT\&F Ciencia, Tecnología y Futuro

ISSN: 0122-5383

ctyf@ecopetrol.com.co

ECOPETROL S.A.

Colombia

Puello-Polo, Esneyder; Ayala G., Mónica; Brito, Joaquín L.

NATURE OF THE ACTIVE PHASE IN HYDRODESULFURIZATION: MOLYBDENUM CARBIDE

SUPPORTED ON ACTIVATED CARBON

CT\&F Ciencia, Tecnología y Futuro, vol. 5, núm. 4, enero-junio, 2014, pp. 61-73

ECOPETROL S.A.

Bucaramanga, Colombia

Available in: http://www.redalyc.org/articulo.oa?id=46532485005

How to cite

Complete issue

- More information about this article

Journal's homepage in redalyc.org

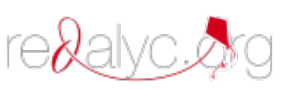

Scientific Information System Network of Scientific Journals from Latin America, the Caribbean, Spain and Portugal Non-profit academic project, developed under the open access initiative 


\title{
NATURE OF THE ACTIVE PHASE IN HYDRODESULFURIZATION: MOLYBDENUM CARBIDE SUPPORTED ON ACTIVATED CARBON
}

\author{
NATURALEZA DE LA FASE ACTIVA EN HIDRODESULFURACIÓN: \\ CARBURO DE MOLIBDENO SOPORTADO SOBRE CARBÓN ACTIVADO
}

\author{
Esneyder Puello-Polo ${ }^{1 *}$, Mónica Ayala G. ${ }^{1}$ and Joaquín L. Brito ${ }^{2}$ \\ 'Línea de Investigación en Oxi/Hidrotratamiento Catalítico, Facultad de Ciencias Básicas, Universidad del Atlántico, \\ Barranquilla, Colombia \\ ${ }^{2}$ Laboratorio de Fisicoquímica de Superficie, Centro de Química, Instituto Venezolano de Investigaciones Científica (IVIC), \\ Caracas, Venezuela \\ e-mail: snypollqco@yahoo.com
}

(Received: Jan. 08, 2014; Accepted: May 29, 2014)

\begin{abstract}
This paper studies the effect of the presulfiding agent and the synthesis method on the catalytic activity of thiophene hydrodesulfurization (HDS), using activated carbon supported molybdenum carbides. The catalytic precursor was prepared by co-impregnation of the support with the ammonium heptamolybdate solution. The conventional carbiding consists of a temperature-programmed treatment under a $\mathrm{CH}_{4} / \mathrm{H}_{2}$ atmosphere at $1073 \mathrm{~K}(\mathrm{MC})$, while the carbothermal method employs pure $\mathrm{H}_{2}$ at $973 \mathrm{~K}(\mathrm{MCH})$. The passivated carbides were characterized by $X$-ray Diffraction (XRD), surface area calculated by the Brunaver-Emmett-Teller multipoint method (BET) and X-ray Photoelectron Spectroscopy (XPS). XRD confirmed the presence of $\beta-\mathrm{Mo}_{2} \mathrm{C}$ for both methods of synthesis, while specific area were in the order of $400 \mathrm{~m} 2 / \mathrm{g}$. XPS showed the presence at the surface of $\mathrm{Mo}^{\delta+}(0 \leq \delta \leq 2), \mathrm{Mo}^{4+}$ and $\mathrm{Mo}^{6+}$, whose abundance was influenced by used synthesis method with greater proportion of high oxidation states in $\mathrm{MCH}$. Prior to catalytic testing, the passivated carbides were presulfided in situ. HDS tests showed that regardless of the presulfiding agent $\left(\mathrm{H}_{2} \mathrm{~S} \circ \mathrm{CS}_{2}\right)$, the carbides obtained by $\mathrm{MCH}$ had higher activity than those obtained using the conventional method. The $\mathrm{B}-\mathrm{Mo}_{2} \mathrm{C}$ presulfiding suggests that the carbides with sulfided surfaces or carbo-sulfide mixtures could be the active phase in HDS.
\end{abstract}

Keywords: Molybdenum carbide, Synthesis method, Hydrodesulfurization, Catalytic hydrotreating, Presulfiding agent.

How to cite: Puello-Polo, E., Ayala, M. G. \& Brito, J. L. (2014). Nature of the active phase in hydrodesulfurization: Molybdenum carbide supported on activated carbon. CT\&F - Ciencia, Tecnología y Futuro, 5(4), 61-74.

*To whom correspondence should be addressed 


\section{RESUMEN}

E

n este trabajo se estudió el efecto del método de síntesis y del agente presulfurante en la actividad catalíitica de hidrodesulfuración (HDS) de tiofeno utilizando carburos de molibdeno soportados sobre carbón activado. El precursor catalítico fue preparado por co-impregnación del soporte con la solución de heptamolibdato de amonio. La síntesis consiste de un tratamiento a temperatura programada utilizando los Métodos Carbotérmico con $\mathrm{H}_{2}(\mathrm{MCH})$ y Convencional (MC) bajo una atmosfera de $\mathrm{CH}_{4} / \mathrm{H}_{2}$ a 973 y 1073 $\mathrm{K}$, respectivamente. Los carburos pasivados se caracterizaron por difracción de rayos $X$ (DRX), área superficial calculada por el método multipunto Brunaver-Emmett-Teller (BET) y espectroscopía fotoelectrónica de rayos $X$ (XPS). Por DRX se comprobó la presencia de $\beta-\mathrm{Mo}_{2} \mathrm{C}$ para ambos métodos de síntesis, mientras que las áreas específicas estuvieron en el orden de los $400 \mathrm{~m}^{2} / \mathrm{g}$. XPS mostró tres tipos de señales de molibdeno asignables a $\mathrm{Mo}^{\delta+}(0 \leq \delta \leq 2), \mathrm{Mo}^{4+}$ y $\mathrm{Mo}^{6+}$ cuya abundancia estuvo influenciada por el método de síntesis con mayor proporción de altos estados de oxidación en el MCH. Antes de los ensayos catalíticos los carburos pasivados fueron presulfurados in situ. Los ensayos de HDS evidenciaron que indistintamente del agente presulfurante $\left(\mathrm{H}_{2} \mathrm{~S} \circ \mathrm{CS}_{2}\right)$, los carburos obtenidos por el $\mathrm{MCH}$ fueron los de mayor actividad que los sólidos obtenidos por el método convencional. Después del proceso de presulfuración los $\beta-\mathrm{Mo}_{2} \mathrm{C}$ fueron modificados, sugiriendo que los carburos con superficies sulfuradas o mezclas de carbosulfuros podría ser la fase activa en HDS.

Palabras clave: Carburo de molibdeno, Método de síntesis, Hidrodesulfuración, Hidrotratamiento catalítico, Agente presulfurante.

\section{RESUMO}

N este trabalho foi estudado o efeito do método de síntese e do agente pressulfurizante na atividade catalítica de hidrodessulfurização (HDS) de tiofeno utilizando carbonetos de molibdênio suportados sobre carvão ativado. O precursor catalítico foi preparado por co-impregnação do suporte com a solução de heptamolibdato de amônio. A síntese consiste de um tratamento a temperatura programada utilizando os Métodos Carbotérmico com $\mathrm{H}_{2}(\mathrm{MCH})$ e Convencional (MC) sob uma atmosfera de $\mathrm{CH}_{4} / \mathrm{H}_{2}$ a 973 e $1073 \mathrm{~K}$, respectivamente. Os carbonetos passivados foram caracterizados por difração de raios $\mathrm{X}$ (DRX), área superficial calculada pelo método multiponto Brunaver-Emmett-Teller (BET) e espectroscopia foto eletrônica de raios $X$ (XPS). Por DRX foi comprovada a presença de $\beta-\mathrm{Mo}_{2} \mathrm{C}$ para ambos os métodos de síntese, enquanto que as áreas específicas estiveram na ordem dos $400 \mathrm{~m}^{2} / \mathrm{g}$. XPS mostrou três tipos de sinais de molibdênio atribuíveis a $\mathrm{Mo}^{\delta+}(0 \leq \delta \leq 2), \mathrm{Mo}^{4+}$ e $\mathrm{Mo}^{6+}$ cuja abundância esteve influenciada pelo método de síntese com maior proporção de altos estados de oxidação no $\mathrm{MCH}$. Antes dos ensaios catalíticos os carbonetos passivados foram pressulfurizados in situ. Os ensaios de HDS evidenciaram que indistintamente do agente pressulfurizante $\left(\mathrm{H}_{2} \mathrm{~S} \circ \mathrm{CS}_{2}\right)$, os carbonetos obtidos pelo $\mathrm{MCH}$ foram os de maior atividade que os sólidos obtidos pelo método convencional. Depois do processo de pressulfurização os $\beta-\mathrm{Mo}_{2} C$ foram modificados, sugerindo que os carbonetos com superfícies sulfuradas ou misturadas de carbosulfetos poderia ser a fase ativa em HDS.

Palavras-chave: Carbonetode molibdênio, Método de síntese, Hidrodessulfurização, Hidrotratamento catalítico, Agente pressulfurizante. 


\section{INTRODUCTION}

The importance of the presence of carbon atoms in the active sulfided phase for the improvement of catalytic properties in hydrodesulfurization (HDS), has led to the generation of catalytic precursors containing organosulfur compounds, whose decomposition generates more active phases than conventional pretreatment (Dufresne et al., 1996; Rueda, Bacaud \& Vrinat, 1997; Vangestel, Leglise \& Duchet, 1994). The inclusion of $C$ in the active phase in HDS was originally reported by Chianelli and Berhault (1999) and Kelty, Berhault and Chianelli (2007), who asserted that the carbon atoms replaced sulfur in the vacancies of the sulfide. This results in a $\mathrm{MoS}_{x} C_{y}$ type species (sulfocarbide), considered to be very active, selective and stable in HDS and hydrodenitrogenation (HDN) processes.

Recently, studies of HDS on metal carbides have shown similar behavior. However, the report by Lee and Boudart (1985) pointed out through characterization studies of post-HDS reaction that there is sulfur at the surface level. Ten years later, Ramanathan and Oyama (1995) conducted a study on the reactions of hydrotreating at high pressure using $\mathrm{Mo}, \mathrm{W}, \mathrm{V}, \mathrm{Nb}$ and $T i$ nitrides and carbides. Their analysis by X-ray Photoelectron Spectroscopy (XPS) of post-reaction catalysts showed the presence of sulfur in the form of sulfate and sulfide on the surface. Similarly, Sajkowski and Oyama (1996) observed similar effects of surface sulfidation in $\gamma-\mathrm{Mo}_{2} \mathrm{~N}$ and $\beta-\mathrm{Mo}_{2} \mathrm{C} / \mathrm{Al}_{2} \mathrm{O}_{3}$ employed in HDS and HDN reactions.

Aegerter et al. (1996) and McCrea et al. (1997) suggested a thin layer of $\mathrm{MoS}_{2}$ as an active site of carbides and nitrides in HDS reactions, highly dispersed over the catalyst surface, and considering $C$ and $N$ as textural promoters. The carbides and nitrides were sulfided with the mixture to be hydtrotreated $\left(\mathrm{C}_{4} \mathrm{H}_{4} \mathrm{~S} / \mathrm{H}_{2}\right)$, by varying the temperature between 600 and $700 \mathrm{~K}$, observing IR spectra of absorbed $\mathrm{CO}$ similar to those of the sulfides $\left(2105 \mathrm{~cm}^{-1}=\mathrm{CO}\right.$ linked to $\mathrm{Mo}_{2}{ }^{+}$coordinatively unsaturated sites (CUS). This suggested that the carbide and nitride surfaces can be sulfided during catalytic reaction. Dhandapani, Clair and Oyama (1998) proposed that the active site of $\mathrm{Mo}_{2} \mathrm{C}$ in HDS reactions is a carbosulfided phase, formed during cumene hydrogenation
(HYD) in the presence of an organosulfur compound, where sulfur absorption occurred at the surface that affected HYD reaction and simultaneously, it induced the HDS of the organosulfur compound.

The catalytic activity of $\mathrm{Mo}_{2} \mathrm{C}$ in HDS reactions results from a surface oxycarbide phase (associated by XPS with a stage of $\mathrm{Mo}^{4+}$ oxidation), which can be sulfided during exposure to the feed, being hydrotreated to form a carbo-sulfide (Manoli et al., 2004; Da Costa et al., 2004; Da Costa, Manoli, Potvin \& DjégaMariadassou, 2005). Density Functional Theory (DFT) was employed to investigate the adsorption of sulfur and the sulfidation of transition metal carbides from groups 4-6, including extended surfaces MC (001), $\mathrm{M}=T i, V$, $M o$, Ta; nanocrystals $M_{14} C_{13}, \mathrm{M}=T i, V, M o$; and MetCar nanoparticles (Metallo Carbohedrenes, $M_{8} C_{12}, \mathrm{M}=T i$, $V, M o$ ). It was discovered that by increasing the $\mathrm{C} / \mathrm{M}$ ratio, the reactivity of the metal carbides toward sulfur decreases in the sequence $\mathrm{Mo}_{2} \mathrm{C}>M_{14} C_{13}>M_{8} C_{12}>\mathrm{MC}$ (001), concluding that corner or edge sites favors the formation of mixed $M_{o} S_{x} C_{y}$ compounds (Liu, Rodríguez \& Muckerman, 2004; Liu, Rodríguez \& Muckerman, 2005). In 2007, a comparative study was conducted between $\mathrm{Mo}_{2} \mathrm{C}$ and $\mathrm{W}_{2} \mathrm{C}$ on the catalytic properties of HDS and HDN, by applying an activation process $\left(\mathrm{H}_{2}\right.$ was used for the HDS reaction and diphenyl sulfide for HDN). The results of High Resolution Transmission Electronic Microscopy (HRTEM) post reaction showed minor extensions of sulfides on the carbide surface where the phenomenon was greater in $\mathrm{Mo}_{2} \mathrm{C}$, which was related to the increased its HDS activity (SzymańskaKolasa, Lewandowski, Sayag \& Djéga-Mariadassou, 2007; Szymańska-Kolasa et al., 2007).

In recent years, Puello-Polo and Brito (2008); PuelloPolo and Brito (2010); Puello-Polo, Gutiérrez-Alejandre, González and Brito (2010), studied the relationship between several synthesis parameters -synthesis method, heating rate and type of precursor- and the effect of catalytic activation by sulfidation in the HDS reaction, through studies of Temperature Programmed Sulfidation (TPS), Temperature Programmed Reaction Spectroscopy (TPRS) and HRTEM. These authors found that the presence of sulfur in the carbide structure was of vital importance in the HDS catalysis, wherefore when using sulfate-base precursors, HDS activities were greater than with regularly used precursors (nitrate 
based) in the CoMo $>$ FeMo $>$ NiMo sequence. This suggests that the formation of carbosulfated species occurs at the surface level ("intimate" mixture between surface sulfides and carbide) and that they are involved in the HDS catalytic activity.

Therefore, the purpose of this research was to assess the effect of the presulfiding process molybdenum carbides supported on passivated and non-passivated activated carbon on the HDS activity of thiophene, obtained by different synthesis methods in order to provide clues to the nature of the active phase. To our knowledge, a great deal of research on hydrodesulfurization avoided the prior activation process by sulfidation on metallic carbides (it is carried out for conventional catalysts), due to their properties similar to the platinum group. Our research group has been pioneering the use of a presulfiding process to modify the oxidic surface of carbides, as a result the inevitable passivation process performed to handle these materials.

\section{THEORETICAL FRAMEWORK}

Hydrotreatment is a process that includes a simultaneous variety of reactions, such as the hydrogenation of unsaturated compounds and hydrogenolysis of carbon-heteroatom bonds to remove sulfur, nitrogen, oxygen and metals. Most petroleum distillation products produced by refineries have been subjected to a hydrotreatment process prior to marketing. Thus, kerosene is subjected to a hydrotreatment process to remove sulfur and to saturate olefins and aromatics. Diesel fuel undergoes a process similar to kerosene to remove sulfur and nitrogen, while vacuum gas oil, which feeds the Fluidized Catalytic Cracker (FCC), is also occasionally hydrotreated in order to eliminate sulfur and nitrogen emissions (Penning, 2001).

To some extent, the additional cost of applying very severe conditions to achieve the levels of sulfur required, could be offset with the use of new catalysts, and to this effect, transition metal carbides have been identified as potential catalysts for such applications, because they have demonstrated excellent catalytic properties in a variety of reactions including: hydrogenation (Djéga-Mariadassou, Boudart, Bugli
\& Sayag, 1995), isomerization (Iglesia, Baumgartner, Ribeiro \& Boudart, 1991), aromatization (Solymosi et al., 1997), hydrodesulfurization (Lee \& Boudart, 1985), hydrodenitrogenation (Al-Megren et al., 2005), hydrodeoxygenation (Dhandapani et al., 1998), hydrodechlorination (Delannoy et al., 2000) and others.

Transition metal carbides are very attractive catalysts due to their tolerance to sulfur poisoning (Liu et al., 2004) and their resistance to the formation of carbon deposits during hydrocarbon reactions (York et al., 1997), both of which are the most common causes of deactivation in metal-based catalysts of the platinum group. However, according to the idea shared by many catalysis researchers, the carbides suffer from a harmful agent as oxygen, which is chemisorbed - either as oxidized surface or atoms interspersed in the crystal lattice of the solid.

Manoli et al. (2004), Da Costa et al. (2004) and Dhandapani et al. (1998) have reported that the HDS catalytic activity of carbides could be due to sulfidation during exposure to the feed to be treated from the oxycarbided phase, with the possible formation of a carbo-sulfide, which raises a question at this point: What phase is involved in the HDS activity? The first authors to suggest a "sulfocarbide" phase were Chianelli and Berhault (1999), resulting in a $M o S_{x} C_{y}$ type stoichiometry considered quite active, selective and stable in HDS and HDN processes. So, many studies (Manoli et al., 2004; Dhandapani et al., 1998; Liu et al., 2004), have reported the formation of such phase, although all activation treatments have always been using hydrogen to eliminate the oxygen present on the catalyst surface. This originated the initial hypothesis by Puello-Polo and Brito (2008); Puello-Polo and Brito (2010) of using presulfiding as an activation process to passivate this type of materials using in HDS.

\section{EXPERIMENTAL DEVELOPMENT}

\section{Synthesis of Activated Carbon Supported Molybdenum Carbides}

The molybdenum precursor supported on activated carbon, was prepared by impregnating microporous 
activated carbon $\left(899 \mathrm{~m}^{2} \mathrm{~g}^{-1}, 0.57 \mathrm{~cm}^{3} \mathrm{~g}^{-1}, 7.95 \AA\right.$ and $\mathrm{pH}_{\mathrm{PZC}}=7$ ) with an aqueous solution of ammonium heptamolybdate at 20\% Mo. Precursor samples were placed in a quartz reactor with quartz fiber bed, passing: (a) $6 \mathrm{~L} / \mathrm{h}$ of a $\mathrm{CH}_{4}(20 \% \mathrm{vol}) / \mathrm{H}_{2}$ mixture heated at 1073 $\mathrm{K}$ (conventional method, MC) and (b) pure $\mathrm{H}_{2}$ heated at $973 \mathrm{~K}$ (carbothermal reduction method, $\mathrm{MCH}$ ). Heating rates of 1 to $5 \mathrm{~K} / \mathrm{min}$ were used to reach carburation temperature. Once carburation temperature was reached, it was held for $1 \mathrm{~h}$ and then the samples were quenched to room temperature and then passivated by $3 \mathrm{~L} / \mathrm{h}$ of $\mathrm{O}_{2}$ (1\%vol)/Ar (Puello-Polo \& Brito, 2008; Puello-Polo \& Brito 2010).

The activated carbon was identified as $M o-C / C . A$ $m-v$, where $M o-C / C . A$ is the molybdenum carbide supported on activated carbon, $m$ the synthesis method $(\mathrm{MC}$ or $\mathrm{MCH})$ and $v$ the heating rate $(1$ or $5 \mathrm{~K} / \mathrm{min})$.

\section{Characterization of Activated Carbon Supported Molybdenum Carbides}

Measurement of the Specific Area using the BET Method

This analysis technique made it possible to find the available adsorption area of the catalyst; therefore the Brunauer-Emmett-Teller multipoint method (BET) was used. The surface area was determined with a ASAP Micromeritics 2010 by $N_{2}$ adsorption at a temperature of $77 \mathrm{~K}$.

\section{X-ray Diffraction (XRD)}

The identification of the different crystalline phases of the precursors and carbides was made using XRD powder analysis. The analysis was carried out with a SIEMENS 5005D diffractometer with a $C u \mathrm{~K} \alpha(1.5456$ $\AA$ ) radiation source, within a range $2 \theta=10-90^{\circ}$. The identification of the different phases was made using the JCPDS library reported in the Newton Square, P.A. (1995) database of the Power Diffraction File (International Center for Diffraction Data).

\section{X-ray Photoelectron Spectroscopy (XPS)}

This analytical technique was used to determine oxidation state, type of compound, chemical environment and surface composition of the carbides. The analyses were carried out using a VG ESCALAB $220 \mathrm{i}$-XL spectrometer, equipped with a dual (no monochromatic) $\mathrm{Mg} / \mathrm{Al}$ anode operated at $400 \mathrm{~W}$. $\mathrm{Al} \mathrm{K} \alpha$ radiation (1486.6
eV) was employed for the experiments reported here. All measurements were performed under UHV $\left(<10^{-9}\right.$ Torr) and calibration of the instrument was done with the $A u 4 f_{7 / 2}$ line at $83.9 \mathrm{eV}$.

Quantitation of the XPS signals and curve fitting of the spectra was carried out with the XPSPEAK 4.1 and XPS GRAPH routines after baseline subtraction by the Shirley method, employing typically an $80 \%$ Gausian-20\% Lorentzian combination and tabulated atomic sensitivity factors. Due to the relatively insulating character of samples, internal referencing of spectrometer energies was made using the dominating $\mathrm{C} 1 \mathrm{~s}$ peak of the support at $284.6 \mathrm{eV}$. Binding energies reported in the current study were accurate to within 0.2 $\mathrm{eV}$. The XPS spectra of Mo $3 \mathrm{~d}$ for carbide $M o-C / C . A-$ $m-v$ samples were deconvoluted using a $2 / 3$ intensity ratio and a $3.2 \mathrm{eV}$ maximum separation by doubles, in reference to the data reported (Portela, Grange \& Delmon, 1995; Ledoux, Pram Huu, Guille \& Dunlop, 1992; Manoli et al., 2004) as: $\mathrm{Mo}^{\delta+}$ (carbide $(0 \leq \delta+$ $\leq 2)$, Mo $3 \mathrm{~d}_{5 / 2}$ binding energy: $\left.228.2 \mathrm{eV} \pm 0.2\right), \mathrm{Mo}^{4^{+}}$ (oxycarbide and/or $\mathrm{MoO}_{2}$, Mo $3 \mathrm{~d}_{5 / 2}$ binding energy: $229.3 \mathrm{eV} \pm 0.2)$, and $\mathrm{Mo}^{6+}\left(\mathrm{MoO}_{3}, \mathrm{Mo} 3 \mathrm{~d}_{5 / 2}\right.$ binding energy: $232.5 \mathrm{eV} \pm 0.2$ ).

Temperature Programmed Sulfidation (TPS) and Temperature Programmed Reduction of Sulfide (TPR-S)

They were used to determine the degree of sulfidation and reductibility of surface sulfides during activation process. Conventional TPS equipped with a continuous flow cell was used, where the $H_{2} S$ was detected with a UV Perkin-Elmer 552 spectrometer and $H_{2}$ consumed by a thermal conductivity detector.

\section{Elemental Analysis CHNO-S}

The analysis determined the sulfur content in the sulfiding carbides or after the HDS reaction. The samples were oxidized at $1000^{\circ} \mathrm{C}$ and chromatographic separation of the resulting gases using an EA 1108 Carlo Erba CHNS-O instrument.

\section{High Resolution Transmission Electron Microscopy} (HRTEM)

Experiments were conducted by high resolution transmission electron microscopy using a JEOL JEM 2010 instrument operated at $200 \mathrm{kV}$ with a line 
resolution of 1.9 to determine the presence of surface sulfides and structural changes in the carbide.

\section{Activation and Testing of Thiophene Hydrodesulfuriza- tion Catalytic Activity}

The following catalytic activation methods were used: (1) without passivation and activation (C-Rx); (2) passivated for $1 \mathrm{~h}$ at room temperature with $3 \mathrm{~L} / \mathrm{h}$ of $\mathrm{O}_{2}(1 \% \mathrm{vol}) / A r$ without activation (P-Rx); (3) without passivation and activation at $673 \mathrm{~K}$ for $2 \mathrm{~h}$ at $6 \mathrm{~L} / \mathrm{h}$ of $C S_{2}(1 \% \mathrm{vol}) / \mathrm{H}_{2}\left(\mathrm{C}-\mathrm{CS}_{2}-\mathrm{Rx}\right)$; (4) passivation and activation at $473 \mathrm{~K}$ and $6 \mathrm{~L} / \mathrm{h}$ of $\mathrm{H}_{2}$ for $2 \mathrm{~h}\left(\mathrm{C}-\mathrm{P}-\mathrm{H}_{2}(473 \mathrm{~K})-\mathrm{Rx}\right)$; (5) passivated and activated at $673 \mathrm{~K}$ and $6 \mathrm{~L} / \mathrm{h}$ of $\mathrm{H}_{2}$ for $2 \mathrm{~h}$ (C-P- $\left.\mathrm{H}_{2}(673 \mathrm{~K})-\mathrm{Rx}\right)$; (6) passivation and activation at $673 \mathrm{~K}$ for $2 \mathrm{~h}$ at $6 \mathrm{~L} / \mathrm{h}$ of $C S_{2}(1 \% \mathrm{vol}) / H_{2}\left(\mathrm{C}-\mathrm{P}-\mathrm{CS}_{2^{-}}\right.$ $\mathrm{Rx})$; (7) passivation and activation at $673 \mathrm{~K}$ for $2 \mathrm{~h}$ at 6 $\mathrm{L} / \mathrm{h}$ of $\mathrm{H}_{2} \mathrm{~S}(15 \% \mathrm{vol}) / \mathrm{H}_{2}$ (C-P- $\mathrm{H}_{2} \mathrm{~S}$-Rx). Passivation was carried out under the same conditions for all treatments.

Once the solid supported ( $0.250 \mathrm{~g})$ was activated in a fixed bed continuous flow reaction system at atmospheric pressure as described above (Puello-Polo \& Brito, 2008; Puello-Polo, 2010), the HDS catalytic activity of the catalyst was measured at $673 \mathrm{~K}$ with a thiophene $(2.27 \% \mathrm{vol}) / \mathrm{H}_{2}$ mixture at $6 \mathrm{~L} / \mathrm{h}$.

Reaction products were analyzed by means of gas chromatography using a VARIAN-3700 chromatograph with an FID detector and a packed column (Porapak) at $443 \mathrm{~K}$, with sampling of the gas effluent occurring at 10 min intervals. After stabilization $(\approx 3 \mathrm{~h})$, the thiophene HDS activity of catalysts were determined and it was expressed as thiophene moles converted into products by grams of catalyst per minute (mol Th/g Cat.min).

\section{RESULTS}

The carbides obtained by $\mathrm{MCH}$ presented higher specific areas (464 and $466 \mathrm{~m}^{2} \mathrm{~g}^{-1}$ ) than those obtained by MC (382 and $\left.400 \mathrm{~m}^{2} \mathrm{~g}^{-1}\right)$ within the same synthesis method, values increased upon increase of the heating rate, as illustrated in Table 1. Regardless the synthesis method, heating rate and post-synthesis presulfiding method (only MC-1 and MCH-5 are shown here) the Figure 1 shows that all the carburized phases have signs of diffraction that are typical of $\beta-\mathrm{Mo}_{2} \mathrm{C}$ (JCPDS $\mathrm{N}^{\mathrm{o}}$ 11-0680), with $2 \theta=39.49,37.93,34.47,52.23,61.65$, 69.64, 74.74 and 75.80; except solid Mo-C/C.A-MCH-5, which shows traces of $\mathrm{MoO}_{2}$, assigned to the low intensity diffraction peaks around $27^{\circ}$ and $53^{\circ}$.

Table 1. Characterization by BET and XPS of Mo-C/C.A. carbides.

\begin{tabular}{|c|cccc|}
\hline Catalyst & $\begin{array}{c}\text { Specific } \\
\text { area } \\
\left(\mathrm{m}^{2} / \mathrm{g}\right)\end{array}$ & \multicolumn{3}{|c|}{$\begin{array}{c}\text { Abundance of surface } \\
\text { Mo by XPS (\%) }\end{array}$} \\
\hline Mo-C/C.A-MC-1 & 382 & 76 & 12 & 12 \\
\hline Mo-C/C.A-MC-5 & 400 & 69 & 10 & 21 \\
\hline Mo-C/C.A-MCH-1 & 464 & 9 & 17 & 74 \\
\hline Mo-C/C.A-MCH-5 & 466 & 4 & 15 & 81 \\
\hline
\end{tabular}

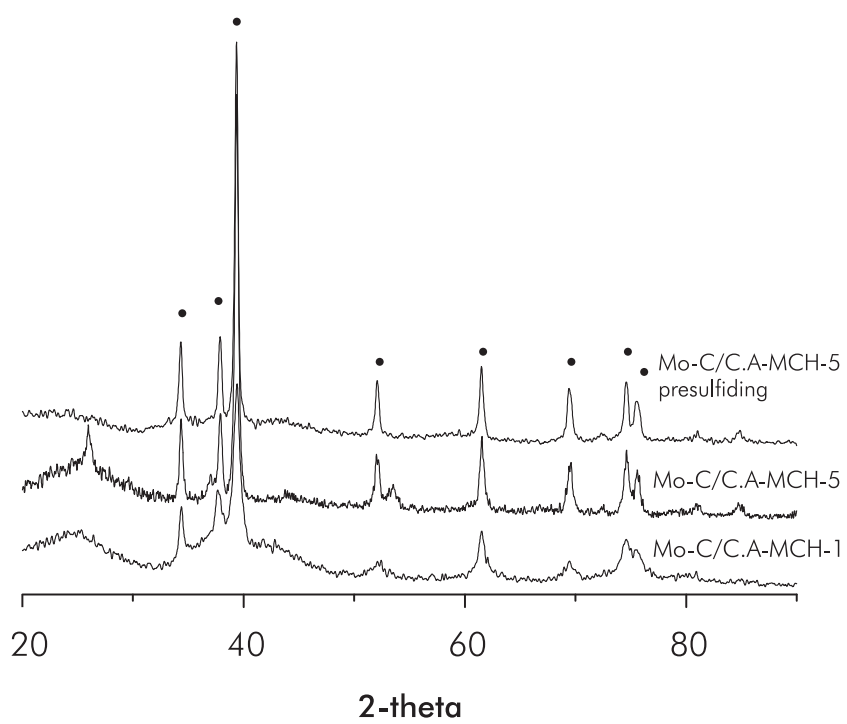

Figure 1. XRD analysis of $M C-1$ and $\mathrm{MCH}-5$ before and after activation by sulfidation. $(\bullet) \beta-\mathrm{Mo}_{2} \mathrm{C}$.

XPS spectra in the Mo $3 d_{5 / 2}$ region for carburized phases of activated carbon supported molybdenum (Portela et al., 1995; Ledoux et al., 1992; Manoli et al., 2004) are listed in Figure 2. The figure shows three types of $\mathrm{Mo}$ signals assignable to carbide $\left(\mathrm{Mo}^{\delta+}, 228.2\right.$ $\mathrm{eV})$, oxycarbide and/or $\mathrm{MoO}_{2}\left(\mathrm{Mo}^{4+}, 229.3 \mathrm{eV}\right)$ and $\mathrm{MoO}_{3}\left(\mathrm{Mo}^{6+}, 232.5 \mathrm{eV}\right)$. The figure shows different species abundances depending on the synthesis method, with the highest proportion of $\mathrm{Mo}^{\delta+}$ species with the conventional synthesis method, while the carbothermal method showed the highest quantity of $\mathrm{Mo}^{4+}$ and $\mathrm{Mo}^{6+}$ species (see Table 1). 


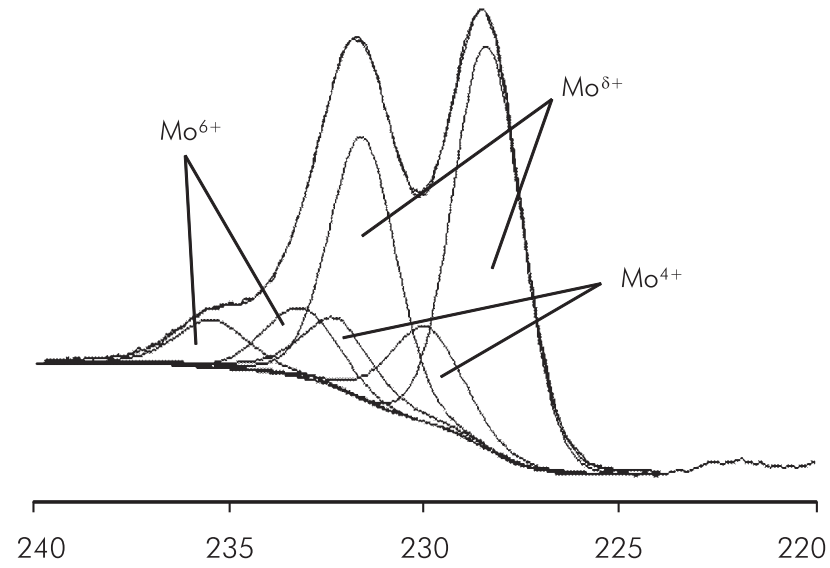

Binding energy (e.V.)

(a)

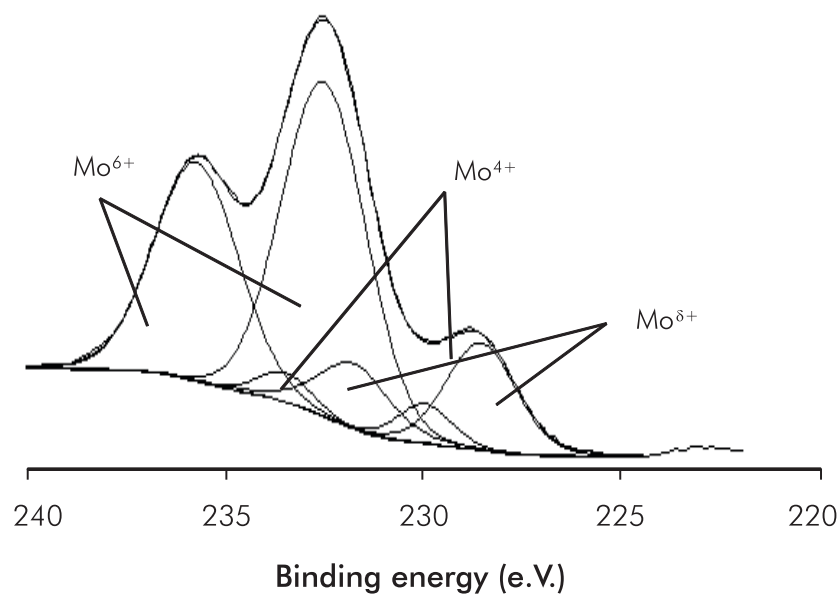

(c)

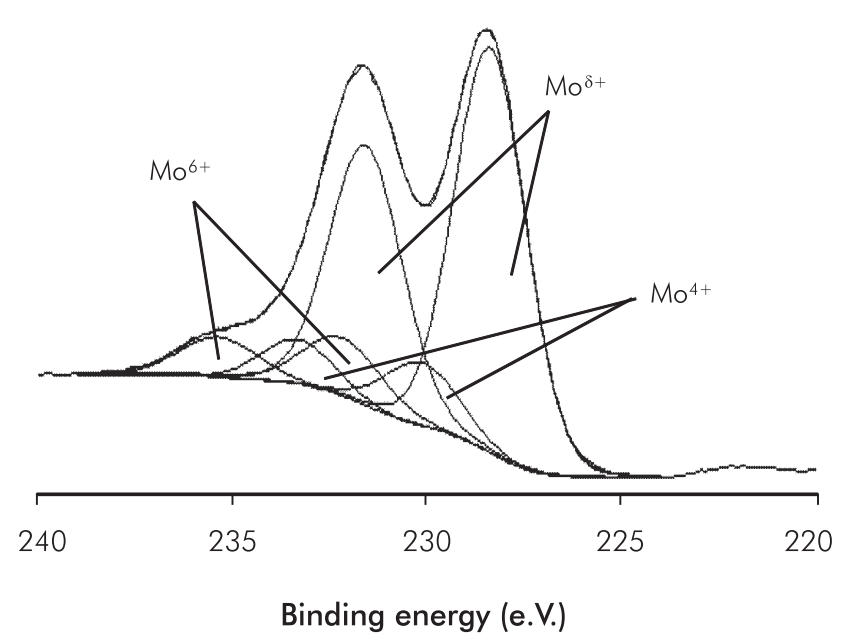

(b)

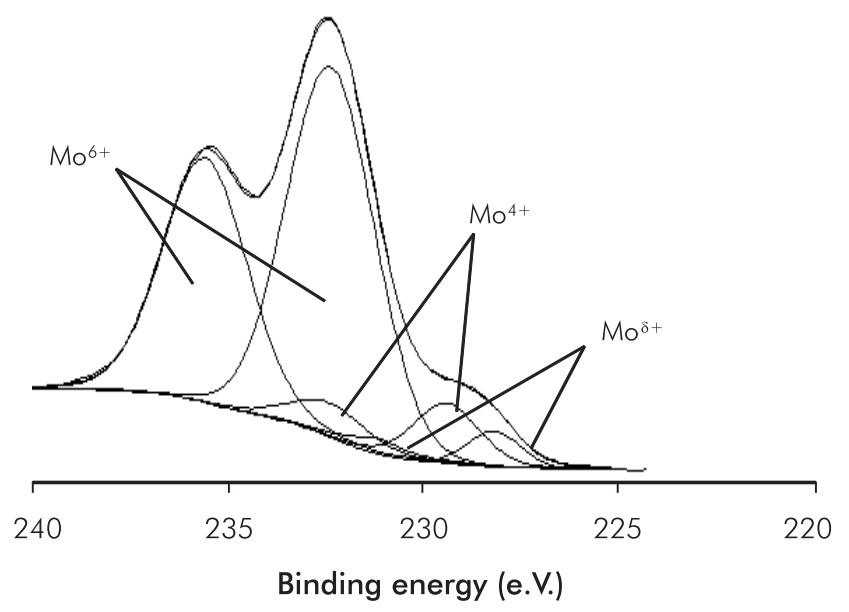

(d)

Figure 2. XPS spectrum in the Mo 3d5/2 region: a) Mo-C/C.A-MC-1, b) Mo-C/C.A-MC-5, c) Mo-C/C.A-MCH-1 and d) Mo-C/C.A-MCH-5.

TPS of the supported carbides shown in Figure 3 consist of broad bands of adsorption-desorption and/ or consumption-production of $\mathrm{H}_{2} \mathrm{~S}$, which are broader than for oxidic solids. Mo carbides exhibit two regions of $\mathrm{H}_{2} \mathrm{~S}$ consumption (Scheffer, Dekker, Mangnus \& Moulijn, 1990): Region I goes up to $673 \mathrm{~K}$ and Region II begins upon reaching $673 \mathrm{~K}$ and is held isothermally for 60 minutes. Between the two regions, there is an intermediate area of $\mathrm{H}_{2} \mathrm{~S}$ production, which is clearly observed for the carbides obtained by the carbothermal method, which is conventionally assigned to oxysulfide reduction with the release of $\mathrm{H}_{2} \mathrm{~S} M o$ (VI) to $\mathrm{Mo}(\mathrm{IV})$, from surface oxidic phases and/or traces of $\mathrm{MoO}_{2}$ in the material synthesized by this method, which is a less reductive method.

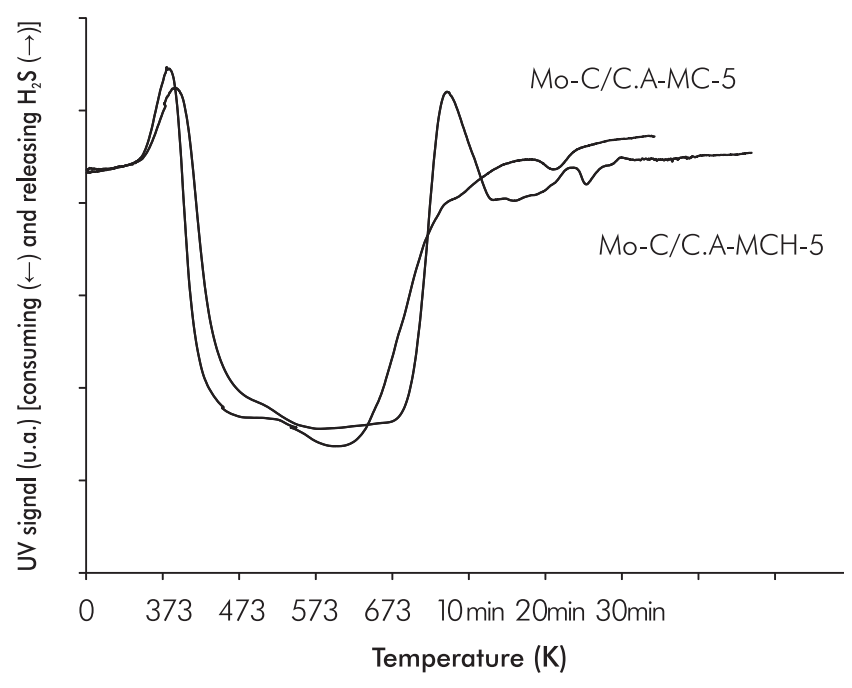

Figure 3. Temperature Programmed Sulfidation (TPS) of Mo-C/C.A phases. 
Figure 4 and Table 2 provide information about the catalyst's capacity to hydrogenate the sulfur generated on the carbide surface. This figure shows three peaks that are characteristic of this type of analysis: one between 0 and $573 \mathrm{~K}$, which will be taken as a single sign. These peaks are due to the reduction in sulfide species $\left(S_{x}\right)$ on coordinatively unsaturated border/corner sites (CUS, sites active in HDS catalysts); another peak between 573 and $923 \mathrm{~K}$ associated with the recombination of -SH groups (condensation) and/or the reaction of - $\mathrm{SH}$ groups with $H_{2}$, and a final peak at $>973 \mathrm{~K}$ corresponding to the total hydrogenation of sulfided species on the carbide surface (Scheffer et al., 1990; Mangnus, Bos \& Moulijn, 1994). For both carburized solids, the first TPR-S peak is observed at a temperature $<473 \mathrm{~K}$ with peak area and intensity greater for the carbide obtained by $\mathrm{MCH}$, which is reflected in a larger proportion of CUS species and the larger quantity of sulfur released (Puello-Polo \& Brito, 2008; Puello-Polo et al., 2010).

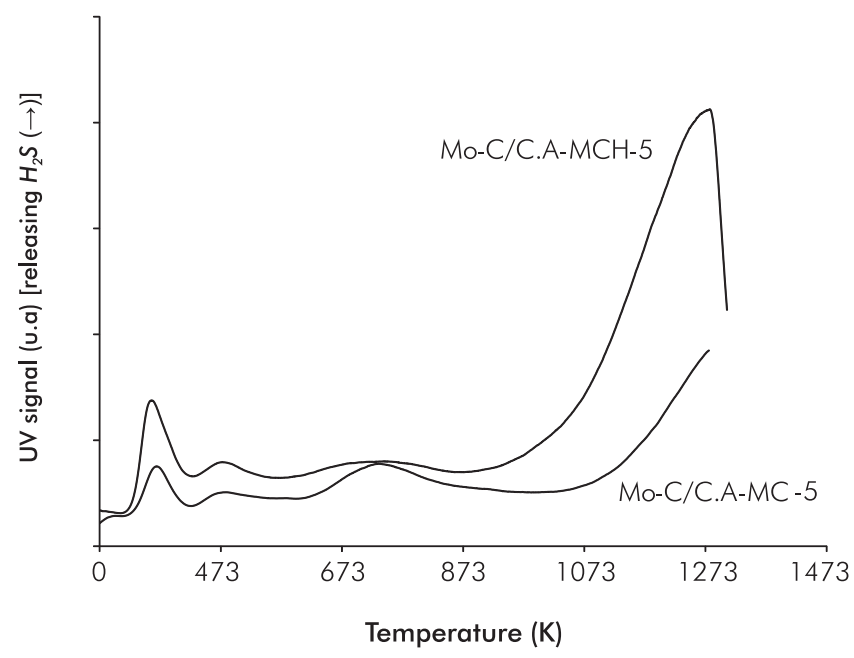

Figure 4. Temperature Programmed Reduction of Sulfide (TPR-S) of Mo-C/C.A phases.
Tables 3 and 4 show the study with XPS and elemental analysis, which reveal that the amount of sulfur present in the carburized solid is influenced by the activation process and synthesis method, where the larger amounts occur when there is a passivation process involved. The post-sulfiding XPS study (Table 4), presented higher abundance of $\mathrm{Mo}^{4+}$ species for $\mathrm{MCH}$ compared to $\mathrm{MC}(47 \%$ vs. $31 \%)$. The Mo-C/C.A$\mathrm{MCH}-5$ sulfidation activation process after with the $\mathrm{CS}_{2} / \mathrm{H}_{2}$ mixture, it continued to show an oxidic phase in high proportion.

Table 3. Sulfur content measured by XPS and Elemental Analysis AE for Mo-C/C.A submitted to various methods of activation.

\begin{tabular}{|llcc|}
\hline \multicolumn{1}{|c}{ Catalyst } & $\begin{array}{l}\text { Activation } \\
\text { Method }\end{array}$ & $\begin{array}{c}\% \text { Atm. } \\
\text { S-XPS }\end{array}$ & $\begin{array}{c}\% \mathrm{p} / \mathrm{p} \\
\text { S-AE }\end{array}$ \\
\hline Mo-C/C.A-MC-1 & C-P-CS - Rx & 9 & 10.67 \\
\hline Mo-C/C.A-m-v & C-P-CS - Rx & 9 & 10.83 \\
\hline Mo-C/C.A-MCH-5 & C-Rx & - & 4.49 \\
\hline Mo-C/C.A-MCH-5 & C-CS - Rx & - & 6.85 \\
\hline
\end{tabular}

Supported carbides obtained by $\mathrm{MCH}$ were more active than those obtained by MC (Tables 2 and 5). Table 5 shows the effect of activation method on catalytic activity, observing that regardless of the method of synthesis, solids presulfided with $\mathrm{H}_{2} \mathrm{~S}$ were more active than those presulfided with $C S_{2}$, while those activated with $\mathrm{H}_{2}$ at 473 and $673 \mathrm{~K}$ only showed greater activity for solids obtained by MC. It is important to mention that in all the cases, the passivation process improved the catalytic activity of HDS.

Carbide sulfidation occurs only on the surface as showed by XRD (after activation) illustrated in Figure 1

Table 2. Relationship between TPR-S of Mo-C/CA (\% sulfided species) and HDS activity ((mol Th conv/gCat $\left.\bullet \mathrm{min}) \times 10^{6}\right)$.

\begin{tabular}{|c|c|c|c|c|}
\hline \multirow{2}{*}{ Catalyst } & $\begin{array}{l}\text { Peak I, } \\
\text { TPR -S }\end{array}$ & $\begin{array}{l}\text { Peak II, } \\
\text { TPR - S }\end{array}$ & $\begin{array}{l}\text { Peak III, } \\
\text { TPR-S }\end{array}$ & HDS \\
\hline & $298-573 \mathrm{~K} / \%$ & $573-923 \mathrm{~K} / \%$ & $>973 \mathrm{~K} / \%$ & $0.1 \mathrm{MPa}$ \\
\hline Mo-C/C.A - MC-5 & 9.4 & 2.4 & 88.1 & 61 \\
\hline Mo-C/C.A - MCH-5 & 13.9 & 21.6 & 64.5 & 110 \\
\hline
\end{tabular}


Table 4. Molybdenum (as percent distribution) and sulfur (as atomic \%) content measured by XPS of Mo-C/C.A following activation with $\mathrm{CS}_{2} / \mathrm{H}_{2}$.

\begin{tabular}{|c|c|c|c|c|}
\hline \multirow{2}{*}{ Solid } & \multicolumn{3}{|c|}{ Mo $3 d_{5 / 2}(\%)$} & \multirow{2}{*}{$\begin{array}{c}\% \text { Atm. } \\
\mathrm{S}_{\text {Total }}\end{array}$} \\
\hline & $M o^{\delta+(0 \leq \delta+\leq 2)}$ & $\mathrm{Mo}^{4+}$ & $\mathrm{Mo}^{6+}$ & \\
\hline Mo-C/C.A-MC-5 & 49 & 31 & 20 & 9 \\
\hline Mo-C/C.A-MCH-5 & 12 & 47 & 41 & 9 \\
\hline
\end{tabular}

Table 5. Thiophene HDS activity of activated carbon supported Mo carbides varying the activation process.

\begin{tabular}{|l|c|c|c|c|}
\hline \multirow{2}{*}{ Treatment } & \multicolumn{5}{c|}{ Activity ((mol Th/g Cat•min) x 10 $)$} \\
\hline C-P-CS - Rx & MC1 & MC5 & MCH1 & MCH5 \\
\hline C-P-H $H_{2} S-R x$ & 80 & 61 & 116 & 109 \\
\hline C-P-H $H_{2}(473 K)-R x$ & - & 84 & 106 & - \\
\hline C-P-H $H_{2}(673 K)-R x$ & 95 & 99 & 105 & 116 \\
\hline C-P-Rx & - & 92 & 102 & - \\
\hline$C-R x$ & - & - & - & 41 \\
\hline$C-C_{2}-R x$ & - & - & - & 63 \\
\hline
\end{tabular}

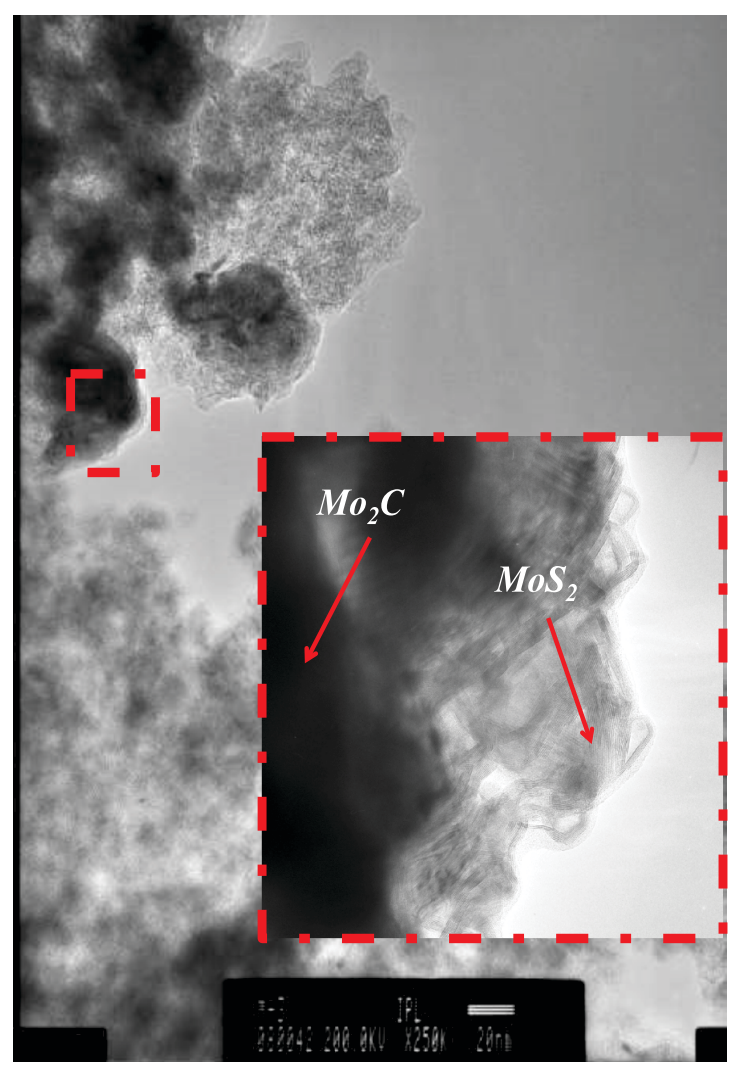

Figure 5. HR-TEM micrography of $\mathrm{MoS}_{2}$ on the Mo-C/C.A-MCH-5 surface following passivation and activation by sulfidation. and characterization by TPR, TPS-R, XPS and HRTEM, where the structural stability of the carbide is observed after activation and only $\mathrm{MoS}_{2}$ at the surface is observed (see Figure 5). Now, not all the molybdenum was sulfided as revealed by DRX, XPS, elemental analysis and HR-TEM results, exhibiting a sulfur content between 8 and $12 \mathrm{wt} \%$ during activation and following passivation, and/or during HDS reaction.

\section{DISCUSSION}

The variation of the specific areas showed Table 1 is presumed to be related with the modification of the support by opening micropores and/or eliminating carbon atoms used to generate the carbide, with a more pronounced effect when the carbide is synthesized by MCH due to the action of $H_{2}$ (Mordenti, Brodzki \& Djéga-Mariadassou, 1998). XRD analysis showed that regardless of the method of synthesis and heating rate, the diffraction peaks were narrow and intense, which means good crystallinity of the $\beta-\mathrm{Mo}_{2} \mathrm{C}$ obtained (see Figure 1). Furthermore, there are no "bulk" structural changes in the carbide after activation process and catalytic reaction as displayed in Figure 1. In the case of the presulfided $\mathrm{Mo}-\mathrm{C} / \mathrm{C} . \mathrm{A}-\mathrm{MCH}-5$ carbide, two spurious signs of $\mathrm{MoO}_{2}$ observed in the carburized solid disappeared. The comparison of the XPS analysis in Mo $3 d_{5 / 2}$ region, before and after presulfidation with XRD, it can be assumed that the changes are at the surface level (see Tables 1, 4 and Figures 1, 2), where the variation in surface molybdenum species for the carbide obtained by $\mathrm{MCH}$ was greater in $\mathrm{Mo}^{4+}$ and $\mathrm{Mo}^{6+}$ species assignable to $\mathrm{MoO}_{2}$ and oxycarbide, which can be sulfided during the activation or HDS catalytic reaction (Manoli et al., 2004; Da Costa et al., 2005).

As mentioned earlier, the synthesis method and heating rate had a great influence on the abundance of molybdenum species at the surface (XPS analysis). This may be due to a higher reducibility induced by the conventional method that consists of a temperatureprogrammed treatment under a $\mathrm{CH}_{4} / \mathrm{H}_{2}$ (1:4) mixture together with the support, both acting as sources of carbon atoms, while the carbothermal method employs only the carbon atoms of the support. However, the MC generates carbon deposition, which possibly "protects" the carbide surface from excessive oxidation. 
The TPS shown in Figure 3 exhibit the sulfidation in two steps (partial and total in Regions I and II, respectively), with a broad $H_{2} S$ adsorption signal for carbides obtained by $\mathrm{MCH}$, which indicates that for samples derived by this synthesis method the amount of oxidic species should be sulfided, thus corroborating the results of XPS pre-activation (see Table 1). Regardless of the method of synthesis, sulfiding of solids occurs at 673 $\mathrm{K}$ after $1 \mathrm{~h}$, which enabled the use of this pretreatment time and temperature prior to the catalytic reaction.

In Figure 4 and Table 2, TPR-S results show that $\mathrm{MCH}$ presented a greater proportion of sulfided species (Puello-Polo \& Brito, 2008; Puello-Polo et al., 2010), which may be due to the higher quantity of high oxidation state species, $\mathrm{Mo}^{4+}$ and $\mathrm{Mo}^{6+}$. In addition, the $H_{2} S$ after presulfiding is probably being retained in the microporous structure of the support, by means of a "sink effect" (Laine, Labady, Severino \& Yunes, 1997), due to the relatively excess sulfur content present after presulfiding than the amount of metal in catalyst (Tables 3 and 4). This is confirmed by the shape of the TPS absorption curve, which is different from the curves conventionally obtained for metallic oxides (Mangnus, Beer \& Moulijn, 1990; Puello-Polo \& Brito, 2008; Puello-Polo et al., 2010).

The XRD analysis before and after sulfidation always showed the presence of $\beta-\mathrm{Mo}_{2} \mathrm{C}$. In addition, the HRTEM micrograph exhibited characteristic stacking of $\mathrm{MoS}_{2}$ crystallites on the carbide surface. The fact that, upon elemental analysis, sulfur percentages yielded results of approximately $10 \%$, it does not mean that the supported carbide was fully sulfided, because the theoretic quantity of sulfur should be $\sim 13 \%$ for the amount of metal used, it would be advisable to degrade the carbide structure altogether -which did not occur (see Figure 1)-, so the accumulation of sulfur in the carbonaceous support "sink effect" could be expected (Puello-Polo \& Brito, 2008; Puello-Polo et al., 2010).

The post-sulfidation XPS study (Table 4) found a greater proportion of $\mathrm{Mo}^{4+}$ for the $\mathrm{MCH}$, which should be related to the formation of CUS, which are useful in the HDS reaction as mentioned by several studies (Manoli et al., 2004; Da Costa et al., 2005), as shown in the quantification by TPS analysis in this paper. The presence of oxygen on the passivated carbide surface (see, Figure 2) did not turn out to be harmful to the catalytic performance, because it causes the formation of surface sulfides by increasing the catalytic activity to thiophene HDS (Table 5), probably due to the formation of a new active site $\left(M o C_{x} S_{y}\right)$. In this sense, the catalysts derived from $\mathrm{MCH}$ showed higher activity than those obtained from MC.

Table 5 shows that for all the methods of activation, the carbides obtained by MC were less active, which may be related to the carbon deposition on the surface (Callant et al., 1993), resulting from the decomposition of $\mathrm{CS}_{2} / \mathrm{H}_{2}\left(\mathrm{CS}_{2}+4 \mathrm{H}_{2} \rightarrow 2 \mathrm{H}_{2} \mathrm{~S}+\mathrm{CH}_{4}, \Delta G=-26.73 \mathrm{kcal} /\right.$ $\mathrm{mol})$ and/or the low sulfidation of surface oxides, whereas the solids pretreated with $\mathrm{H}_{2}$ have more activity as consequence of the carbon removal deposited on the surface and/or the reduction of surface oxide (Lee et al., 1988). Nevertheless, as reported by Leary, Michaels and Stacy (1986), the oxygen incorporated in the carbide upon passivation is not completely eliminated by the mere reduction with $H_{2}$, and it remains inside the carbide structure. Therefore, the importance of this is to explain the value of passivation in the activation process of carburized catalysts prior to HDS reaction (Tables 2 and 5), which is related to nature of the active sites in these systems by the formation during activation and/ or HDS reaction of $\mathrm{MoS}_{x} \mathrm{C}_{y}$ and $\mathrm{MoS}_{2}$ type species (see Figure 5), while the absence of passivation (see, Table 5), suggesting that the sulfur would be absorbed on the carbide more strongly poison the catalyst, as proposed by Liu et al. (2004); Liu et al. (2005).

\section{CONCLUSIONS}

- The specific areas of the supported carbides are smaller than those of the support, between $360-466 \mathrm{~m}^{2} / \mathrm{g}$. In addition, no correlation was found between the specific area of the carbides and thiophene HDS activity. The presence of $\mathrm{Mo}^{\delta+}, \mathrm{Mo}^{4+}$ and $\mathrm{Mo}^{6+}$ on the carbide surface was revealed by XPS and the relative proportions of surface species depends on the synthesis method and heating rate. The carbothermal method generated a large proportion of high oxidation state species $\left(\mathrm{Mo}^{4+}\right.$ and $\left.M o^{6+}\right)$. The abundance on surface of species $\mathrm{Mo}^{4+}$ (oxicarbides) and/or $\mathrm{MoO}_{2}$ (detected by XPS) was positively correlated with HDS activities. The surface sulfidation of oxidic species was demonstrated by 
XRD, XPS, TPS, TPR-S and HRTEM before and after reaction-activation that the bulk was not affected. The results of XPS, TPS, TPR-S and DRX postreaction suggest that a large part of the sulfur added by means of presulfiding does not necessarily result in an optimum sulfo-carbide active phase and it is probably being retained in the microporous structure of the carbon activated by means of a "sink effect". The area of the first TPR-S peak -coordinatively unsaturated sites (CUS)- was correlated with the HDS activity. Since the carbides showed greater catalytic activity when they were presulfided as compared with catalysts not submitted to sulfiding procedures, suggesting that the carbides with sulfided surfaces or mixed carbo-sulfide species could be the active phase in HDS on carbide catalysts.

\section{ACKNOWLEDGEMENTS}

The authors would like to thank FONACIT for fun-ding the G-2000001537 project and the technical support provided by Carlos Bastidas (XRD); Alberto Albornoz (XPS); Petra Hernández and Eleinne Severino (CHNS-O); and Iván Puente Lee (HRTEM). E.P.P dedicated to Ofelia Polo (R.I.P.) and the LIOHCUA research line.

\section{REFERENCES}

Aegerter, P. A., Quigley, W. W. C., Simpson, G. J., Ziegler, D. D., Logan, J. W., McCrea, K. R., Glazier, S. \& Bussell, M. E. (1996). Thiophene hydrodesulfurization over alumina-supported molybdenum carbide and nitride catalysts: Adsorption sites, catalytic activities, and nature of the active surface. J. Catal., 164(1), 109-121.

Al-Megren, H. A., Xiao, T., González-Cortés, S. L., AlKhowaiter, S. H. \& Green, M. L. H. (2005). Comparison of bulk CoMo bimetallic carbide, oxide, nitride and sulfide catalysts for pyridine hydrodenitrogenation. J. Mol. Catal. A: Chem., 225(2), 143-148.

Callant, M., Grange, P., Holder, K. A., Viehe, H. G. \& Delmon, B. (1993). Secondary effects in catalytic tests for hydrodenitrogenation reactions due to side reactions with sulfur compounds. J. Catal., 142(2), 725-728.
Chianelli, R. R. \& Berhault, G. (1999). Symmetrical synergism and the role of carbon in transition metal sulfide catalytic materials. Catal. Today, 53(3), 357-366.

Da Costa, P., Manoli, J. M., Potvin, C. \& Djéga-Mariadassou, G. (2005). Deep HDS on doped molybdenum carbides: from probe molecules to real feedstocks. Catal. Today, 107-108: 520-530.

Da Costa, P., Potvin, C., Manoli, J. M., Genin, B. \& DjégaMariadassou, G. (2004). Deep hydrodesulphurization and hydrogenation of diesel fuels on alumina-supported and bulk molybdenum carbide catalysts. Fuel, 83(13), 17171726.

Delannoy, L., Giraudon, J. M., Granger, P., Leclercq, L. \& Leclercq, G. (2000). Group VI transition metal carbides as alternatives in the hydrodechlorination of chlorofluorocarbons. Catal. Today, 59(3-4), 231-240.

Dhandapani, B., Clair, T. St. \& Oyama, S. T. (1998). Simultaneous hydrodesulfurization, hydrodeoxygenation, and hydrogenation with molybdenum carbide. Appl. Catal. A: Gen., 168(2), 219-228.

Djéga-Mariadassou, G., Boudart, M., Bugli, G. \& Sayag, C. (1995). Modification of the surface composition of molybdenum oxynitride during hydrocarbon catalysis. Catal. Lett., 31(4), 411-420.

Dufresne, P., Brahma, N., Labruyère, F., Lacroix, M. \& Breysse, M. (1996). Activation of off site presulfided cobalt-molybdenum catalysts. Catal. Today, 29(1-4), 251-254.

Iglesia, E., Baumgartner, J. E., Ribeiro, F. H. \& Boudart, M. (1991). Bifunctional reactions of alkanes on tungsten carbides modified by chemisorbed oxygen. J. Catal. 131(2), 523-544.

Kelty, S. P., Berhault, G. \& Chianelli, R. R. (2007). The role of carbon in catalytically stabilized transition metal sulfides. Appl. Catal. A: Gen., 322: 9-15.

Laine, J., Labady, M., Severino, F. \& Yunes, S. (1997). Sink effect in activated carbon-supported hydrodesulfurization catalysts. J. Catal., 166(2), 384-387.

Leary, K. J., Michaels, J. N. \& Stacy, A. M. (1986). Carbon and oxygen atom mobility during activation of $\mathrm{Mo}_{2} \mathrm{C}$ catalysts. J. Catal., 101(2), 301-313.

Ledoux, M. J., Pram Huu, C., Guille, J. \& Dunlop, H. (1992). Compared activities of platinum and high specific surface 
area $\mathrm{Mo}_{2} \mathrm{C}$ and $\mathrm{WC}$ catalysts for reforming reactions: I. Catalyst activation and stabilization: Reaction of nhexane. J. Catal., 134(2), 383-398.

Lee, J. S. \& Boudart, M. (1985). Hydrodesulfurization of thiophene over unsupported molybdenum carbide. Appl. Catal., 19(1), 207-210.

Lee, J. S., Volpe, L., Ribeiro, H. \& Boudart, M. (1988). Molybdenum carbide catalysts: II. Topotactic synthesis of unsupported powders. J. Catal., 112(1), 44-53.

Liu, P., Rodríguez, J. A. \& Muckerman, J. T. (2004). The $T_{i} C_{12}$ Metcar: A new model catalyst for hydrodesulfurization. J. Phys. Chem. B., 108(49), 18796-18798.

Liu, P., Rodríguez, J. A. \& Muckerman, J. T. (2005). Sulfur adsorption and sulfidation of transition metal carbides as hydrotreating catalysts. J. Mol. Cat. A: Chem., 239(12), 116-124.

Mangnus, P., Bos, A. \& Moulijn, J. (1994). Temperatureprogrammed reduction of oxidic and sulfidic aluminasupported $\mathrm{NiO}, \mathrm{WO}_{3}$, and $\mathrm{NiO}-\mathrm{WO}_{3}$ catalysts. J. Catal., 146(2), 437-448.

Mangnus P., de Beer, V. H. J. \& Moulijn, J. (1990). Influence of phosphorus on the structure and the catalytic activity of sulfided carbon-supported Co-Mo catalysts. Appl. Catal., 67(1), 119-139.

Manoli, J. M., Da Costa, P., Brun, M., Vrinat, M., Maugé, F. \& Potvin, C. (2004). Hydrodesulfurization of 4,6-dimethyldibenzothiophene over promoted $(N i, P)$ aluminasupported molybdenum carbide catalysts: activity and characterization of active sites. J. Catal., 221(2), 365-377.

McCrea, K. R., Logan, J. W., Tarbuck, T. L., Heiser, J. L. \& Bussell, M. E. (1997). Thiophene hydrodesulfurization over alumina-supported molybdenum carbide and nitride catalysts: Effect of Mo loading and phase. J. Catal., 171(1), 255-267.

Mordenti, D., Brodzki, D. \& Djéga-Mariadassou, G. (1998). New synthesis of $\mathrm{Mo}_{2} \mathrm{C} 14 \mathrm{~nm}$ in average size supported on a high specific surface area carbon material. J. Sol. St. Chem., 141(1), 114-120.

Penning, R. T. (2001). Petroleum refining: a look at the future. Hydrocarb. Process., 80(2), 45-46.
Portela, L., Grange, P. \& Delmon, B. (1995). XPS and NO adsorption studies on alumina-supported $\mathrm{Co}-\mathrm{Mo}$ catalysts sulfided by different procedures. J. Catal., 156(2), 243-254.

Power Diffraction File. (1995). International Center for Diffraction Data. Newtown Square, Philadelphia.

Puello-Polo, E. \& Brito, J. L. (2008). Effect of the type of precursor and the synthesis method on thiophene hydrodesulfurization activity of activated carbon supported $\mathrm{Fe}-\mathrm{Mo}, \mathrm{Co}-\mathrm{Mo}$ and Ni-Mo carbides. J. Mol. Catal. A: Chem., 281(1-2), 85-92.

Puello-Polo, E. \& Brito, J. L. (2010). Effect of the activation process on thiophene hydrodesulfurization activity of activated carbon supported bimetallic carbides. Catal. Today, 149(3-4), 316-320.

Puello-Polo, E., Gutiérrez-Alejandre, A., González, G. \& Brito, J. L. (2010). Relationship between sulfidation and HDS catalytic activity of activated carbon supported $\mathrm{Mo}, \mathrm{Fe}-\mathrm{Mo}$, Co-Mo and $\mathrm{Ni}-\mathrm{Mo}$ carbides. Catal. Lett., 135(3-4), 212-218.

Ramanathan, S. \& Oyama, S. T. (1995). New catalysts for hydroprocessing: Transition metal carbides and nitrides. J. Phys. Chem., 99(44), 16365-16372.

Rueda, N., Bacaud, R. \& Vrinat, M. (1997). Highly dispersed, nonsupported molybdenum sulfides. J. Catal., 169(1), 404-406.

Sajkowski, D. J. \& Oyama, S. T. (1996). Catalytic hydrotreating by molybdenum carbide and nitride: Unsupported $\mathrm{Mo}_{2} \mathrm{~N}$ and $\mathrm{Mo}_{2} \mathrm{ClAl}_{2} \mathrm{O}_{3}$. Appl. Catal. A: Gen.,134(2), 339-349.

Scheffer, B., Dekker, N., Mangnus, P. \& Moulijn, J. (1990). A temperature-programmed reduction study of sulfided $\mathrm{CoMo} / \mathrm{Al}_{2} \mathrm{O}_{3}$ hydrodesulfurization catalysts. J. Catal., 121(1), 31-46.

Solymosi, F., Cserényi, J., Szöke, A., Bánsági, T. \& Oszkó, A. (1997). Aromatization of methane over supported and unsupported Mo-based catalysts. J. Catal., 165(2), $150-161$.

Szymańska-Kolasa, A., Lewandowski, M., Sayag, C. \& Djéga-Mariadassou, G. (2007). Comparison of molybdenum carbide and tungsten carbide for the hydrodesulfurization of dibenzothiophene. Catal. Today, 119(1-4), 7-12. 
Szymańska-Kolasa, A., Lewandowski, M., Sayag, C., Brodzki, D. \& Djéga-Mariadassou, G. (2007). Comparison between tungsten carbide and molybdenum carbide for the hydrodenitrogenation of carbazole. Catal. Today, 119(1-4), 35-38.

Vangestel, J., Leglise, J. \& Duchet, J. C. (1994). Catalytic properties of a $\mathrm{CoMo} / \mathrm{Al}_{2} \mathrm{O}_{3}$ catalyst presulfided with alkyl polysulfides: Comparison with conventional sulfiding. J. Catal., 145(2), 429-436.

York, A. P. E., Claridge, J. B., Brungs, A. J., Tsang, S. C. \& Green, M. L. H. (1997). Molybdenum and tungsten carbides as catalysts for the conversion of methane to synthesis gas using stoichiometric feedstocks. Chem. Commun., 1: 39-40.

\section{AUTHORS}

\section{Esneyder Puello Polo}

Affiliation: Universidad del Atlántico

Chemist, Universidad de Cartagena

$\mathrm{Ph}$. D. in Science, Instituto Venezolano de Investigaciones Cientificas e-mail: snypollqco@yahoo.com

\section{Mónica Ayala G.}

Affiliation: Universidad del Atlántico

Chemistry Student, Universidad del Atlántico

e-mail: moni290192@hotmail.com

\section{Joaquín L. Brito}

Affiliation: Instituto Venezolano de Investigaciones Cientificas Chemist, Universidad Simón Bolivar, Venezuela

$\mathrm{Ph}$. D. in Science, Instituto Venezolano de Investigaciones Cientificas e-mail: joabrito@ivic.ve 
